\title{
Nature as God: A juxtaposition of Vito Mancuso and Alexander von Humboldt in their search for understanding reality
}

\begin{tabular}{|c|c|}
\hline \multicolumn{2}{|c|}{$\begin{array}{l}\text { Authors: } \\
\text { Johan Buitendag }^{1} \text { (D) } \\
\text { Corneliu C. Simut }^{1,2}\end{array}$} \\
\hline \multicolumn{2}{|c|}{$\begin{array}{l}\text { Affiliations: } \\
{ }^{1} \text { Department of Systematic } \\
\text { and Historical Theology, } \\
\text { Faculty of Theology and } \\
\text { Religion, University of } \\
\text { Pretoria, Pretoria, } \\
\text { South Africa }\end{array}$} \\
\hline \multicolumn{2}{|c|}{$\begin{array}{l}{ }^{2} \text { Department of Theology and } \\
\text { Social- Humanistic Sciences, } \\
\text { Faculty of Theology, Emanuel } \\
\text { University, Oradea, Romania }\end{array}$} \\
\hline \multicolumn{2}{|c|}{$\begin{array}{l}\text { Corresponding author: } \\
\text { Johan Buitendag, } \\
\text { johan.buitendag@tuks.co.za }\end{array}$} \\
\hline \multicolumn{2}{|c|}{$\begin{array}{l}\text { Dates: } \\
\text { Received: } 05 \text { Feb. } 2021 \\
\text { Accepted: } 02 \text { Apr. } 2021 \\
\text { Published: } 19 \text { May } 2021\end{array}$} \\
\hline \multicolumn{2}{|c|}{$\begin{array}{l}\text { How to cite this article: } \\
\text { Buitendag, J. \& Simut, C.C., } \\
\text { 2021, 'Nature as God: A } \\
\text { juxtaposition of Vito } \\
\text { Mancuso and Alexander von } \\
\text { Humboldt in their search for } \\
\text { understanding reality', } \\
\text { HTS Teologiese Studies/ } \\
\text { Theological Studies } \\
\text { 77(3), a6525. https://doi. } \\
\text { org/10.4102/hts.v77i3.6525 }\end{array}$} \\
\hline \multicolumn{2}{|c|}{$\begin{array}{l}\text { Copyright: } \\
\text { (c) 2021. The Authors. } \\
\text { Licensee: AOSIS. This } \\
\text { is licensed under the } \\
\text { Creative Commons } \\
\text { Attribution License. }\end{array}$} \\
\hline \multicolumn{2}{|l|}{ Read online: } \\
\hline 回的回 & $\begin{array}{l}\text { Scan this QR } \\
\text { code with your } \\
\text { smart phone or } \\
\text { mobile device } \\
\text { to read online. }\end{array}$ \\
\hline
\end{tabular}

This article's premise is that science holds the promise of deepening religious perspectives on creation. The natural sciences have convincingly proved that nature is not static, or a ready-made creation dropped from heaven. Theologians need to read nature as scientists see it and engage with that understanding theologically.

The concept of resonance is applied to denote this tangential relationship as an eco-social constructivist understanding of reality. Two proponents, one scientist and one theologian, have been chosen who share this view of a holistic reality, and the objective is to determine the degree of resonance viable of these magisteria. A method of polycentric hermeneutics is thus pursued.

Although we referred to the concept of consilience regarding von Humboldt's enterprise, it is not in the authors' scope to achieve this with science and theology as disciplines sui generis. However, if resonance becomes vital in understanding reality, faith is inevitable (Anselm). If a creation theology seeks a degree of plausibility, it requires the feedback-loop methodology of science. We all share one earth: the closer we all come to a shared end, the closer we also come together and relativise differences. The naturalist Edward O. Wilson suggested that science and religion should set aside their differences to save the planet. Resonance has the potential to let new horizons emerge in our mutual endeavour to come to grips with reality and to map out certain tangentially overlapping magisteria.

Contribution: Through resonance, the thought constructs of a scientist and a theologian are juxtaposed. An iterative hermeneutics' importance is emphasised in the theology and science discourse, if faith seeks understanding and leads to awe. And the conclusion is that the 'spiritual dimension' and the 'natural dimension' do not only overlap but are tangential, as they engage with the same reality.

Keywords: theology and science dialogue; Alexander von Humboldt; Vito Mancuso; nature as God; eco-hermeneutics; resonance; cosmos; naturalism; holism; aesthetics; theology of nature.

\section{Raison D'être}

This article is investigational, a Gedanken experiment. It designates the generative work of imagination, known as 'virtual reality'. It gets its clue from Stephen Jay Gould's idea of 'nonoverlapping magisteria' regarding the conflict between science and religion. His view is that:

$[N]$ o conflict should exist because the magisteria of science and religion do not overlap. According to the principle of NOMA - 'nonoverlapping magisteria' - science covers the empirical universe, while religion covers questions of moral meaning and ethical value (Gould 2014:7).

Instead of this distinction, but still with the same objective, we try to indicate that the dividing wall between science and faith is a porous membrane and a converted application, applying the acronym TOMA, or 'tangentially overlapping magisteria', augments this enterprise (cf. Brown 2010:17). But this could come at a price, and the question is to what extent belief could be left behind? It is about the way the devout mind sees the world investigated by science.

The authors believe that theology is, in principle, an endeavour to understand reality, as all sciences are trying to do. Ted Peters formulates it aptly when he says an 'ontological thirst' is present in science and theology, although with a pluralism of rationalities. Science and 
theology both shun delusion. 'Both are pursued by truth-seeking communities. Both are willing to subject ordinary knowledge to scrutiny and to humbly accept correction, revision, and correction' (Peters, Russel, \& Welker 2002:xiii). And the challenge, of course, is to stay faithful to a discipline's core values. Yet, we cannot admit a contradiction between two ideas (Schleiermacher [1999] 2008):

Within this range our proposition admits no distinction; in each and every situation we ought to be conscious of, and sympathetically experience, absolute dependence on God just as we conceive each and everything as completely conditioned by the interdependence of nature. (p. 171)

This article's premise is that science holds the promise of deepening religious perspectives on creation. The natural sciences have convincingly proved that nature is neither static nor a 'ready-made creation dropped from heaven' (Brown 2010:8). Theologians need to read nature as scientists see it and engage with that understanding. John Haught applies the term 'consonance' not less than 11 times to indicate something of this proposed converse model of his: 'The contact approach, therefore, is concerned that theology always remains positively "consonant" with cosmology' (1995:18).

Perhaps the word 'resonance' is a better option to describe this tangential relationship of an eco-social constructivist understanding of reality: 'An eco-sociological (eco-theological) understanding of homo religiosus is therefore to assume human life as ontologically distributed' (Buitendag 2012:1). Warren Brown (to be distinguished from William P. Brown) applied the word resonance as a model for relating science, psychology and faith (Brown 2004). It is rather evident that this resonance will be symbolic and virtual, as a mere correspondence could be ruled out. They are analogous constructs based on imaginative associations. It is important to note that we apply Brown's insights of Biblical creation texts only analogically and do not limit ourselves to his plea for a 'canonical consonance' (2010:227). The inkling of David Tracy (2010:1), 'how does experiencing a limit to dialogical-hermeneutical understanding also open dialogue to new non-dialogical ways of thinking in the transcendent-immanent realm of the Infinite, the Incomprehensible', is rather the focus.

Two proponents, one scientist and one theologian, have been chosen who share this view of a holistic reality. The objective is to determine the degree of resonance viable of the magisteria involved.

Friedrich Wilhelm Heinrich Alexander von Humboldt ${ }^{1}$ conceived the web of life, that is, the concept of an integrated nature as

1.Friedrich Wilhelm Heinrich Alexander von Humboldt FRS (14 September 1769-06 May 1859) was a Prussian geographer, naturalist, explorer and influential proponent of Romantic philosophy and science.

He was the younger brother of the Prussian minister, philosopher and linguist Wilhelm von Humboldt (1767-1835). Humboldt's quantitative work on botanical geography laid the foundation for the field of biogeography. Humboldt's advocacy geography laid the foundation for the field of biogeography. Humboldt's advocacy of long-term systematic geophysical measurement laid the foundation for modern geomagnetic and meteorological monitoring. Between 1799 and 1804, Humbold travelled extensively in Latin America, exploring and describing it for the first tim from a modern scientific point of view. His description of the journey was written up and published in an enormous set of volumes over 21 years. Humboldt was one of the first people to propose that the lands bordering the Atlantic Ocean were once
joined (South America and Africa in particular). Humboldt resurrected the use of the we know it today. Von Humboldt published extensively, and his opus magnum was the multivolume Cosmos - a sketch of the physical description of the universe (Von Humboldt 1858). Let us hear his voice in this regard:

When the human mind first attempts to subject to its control the world of physical phenomena, and strives by meditative contemplation to penetrate the rich luxuriance of living nature, and the mingled web of free and restricted natural forces, man feels himself raised to a height from whence, as he embraces the vast horizon, individual things blend together in varied groups, and appear as if shrouded in a vapory vail. These figurative expressions are used in order to illustrate the point of view from whence we would consider the universe both in its celestial and terrestrial sphere. (p. 104)

'Cosmos', adds Von Humboldt, entails the 'universal all' together with an 'adornment of this universal order'. Von Humboldt deserves to be restored to his rightful place in the scholarly pantheon of nature and science, and even more, science and religion. He succeeded in distinguishing between internal and external forces that shape organisms, opening a vista for the interconnectedness of the whole of reality. 'Humboldt applied them [i.e., forces] to nature on a much broader level - interpreting the natural world as a unified whole that is animated by interactive forces' (Wulf 2015:35).

On the other hand, Vito Mancuso ${ }^{2}$ underscores this view and understands nature in a very close connection to the spirit, even to the point that the two coincide. His fundamental thesis regarding nature's reality is expressed by his conviction that 'nature is spirit' (Mancuso 2002:29). The thesis's corollary consists of another basic philosophical equation that emphasises the identity between nature and God. In Mancuso's words, 'nature is God' (Mancuso 2002:29), which is, paradoxically, an affirmation of God's absence, to the very least from the perspective of traditional understandings of God as supernatural, transcendent, ontologically real and characterised by absolute alterity.

These two hypotheses are crucial for Mancuso's perspective on nature. In identifying nature as both spirit and God, he steps beyond traditional Christianity's confines into the realm of world religions and even farther away, into the broad spectrum of non-religious and secular perspectives on reality. This, of course, makes him a worthy spiritual discussion partner of Von Humboldt.

\footnotetext{
word cosmos from the ancient Greek and assigned it to his multi-volume treatise, Kosmos, in which he sought to unify diverse braches culture. This important work also motivated a holistic perception of the universe as one interacting entity. He was the first person to describe the phenomenon and cause of human-induced climate change, in 1800 and again in 1831, based on observations generated during his travels.

https://makingscience.royalsociety.org/s/rs/people/fst00054219\#: :text= Friedrich $\% 2$ Wilhelm $\% 2$ Heinrich $\% 20$ Alexander $\% 2$ von, of $\% 20$ Romantic $\% 20$ philosophy $\% 20$ and $\% 20$ science.\&text=Humboldt's $\% 2$ quantitative $\% 20$ work $\% 20$ on $\% 20$ botanical,for $\% 20$ the $\% 20$ field $\% 20$ of 20 biogeography (Accessed 01 February 2021).

2.Vito Mancuso (born 09 December 1962 in Carate Brianza of Sicilian parents) is a doctor in systematic theology. Of the three academic degrees of the theological course, he obtained a Baccalaureate from the Theological Faculty of Northern Italy in Milan, a licentiate from the Pontifical Theological Faculty of Southern Italy San Tommaso d'Aquino in Naples, and a doctorate in Rome from the Pontifical University Lateran. From 2013 to 2014, he was professor of History of Theologica Doctrines' at the University of Padua. Prior to this, he was a professor of theology a the Faculty of Philosophy of the Vita-Salute San Raffaele University in Milan from 2004 to 2011. From 2009 to 2017, he collaborated with the newspaper La Repubblica.
} 
This article strives not only to juxtapose the insights of a scientist and a theologian but particularly to map a degree of resonance in a theology that has disembarked from a static or superstitious view of nature. Of course, the choice of these proponents is subjective, yet deliberate, ${ }^{3}$ as Von Humboldt is relatively unexplored in theological thinking and so is the Italian scholar in Protestant theology, who tries to bridge this gap by presenting not necessarily a vocabulary but perhaps a 'grammar' (Michener 2013:6-8) for our deliberations about understanding reality. The other question to be answered in the end is to what extent is this resonance (synergy and symbiosis) viable without compromising the creeds of faith. Therefore, the dialogue is not between science and philosophy per se, but between science and theology, at least within our scholarly and belief frames of reference (Lindbeck 1984):

Intratextual theology redescribes reality within the scriptural framework rather than translating Scripture into extrascriptural categories. It is the text, so to speak, which absorbs the world, rather than the world the text. (p. 5)

'Identifying and exploring "virtual parallels" is a way of imaginatively interrelating science and faith without surrendering the integrity of one to the other' (Brown 2010:10), which is our task.

\section{Nature as God}

Vito Mancuso provides an upfront critique of what he calls 'revealed religions' - Judaism, Christianity and Islam - for their dependence on sacred books which place God beyond nature, not within it. ${ }^{4}$ Mancuso's criticism is anchored in his adherence to Hegelian philosophy which synthesises transcendence and immanence into a single reality, that of nature, characterised by space, time and matter (Simut 2011:169). However, in his thought, the coessentiality between nature and spirit, and ultimately between nature and God, reveals what Mancuso describes as 'the spiritual dimension' of nature (Mancuso 2002:29). The spirit confirms the absence of God within nature. Nature is fundamentally, essentially and intrinsically spiritual; the very ontology of nature consists of spirituality. As part of his criticism of Judaism, Christianity and Islam, Mancuso notices that in all these three revealed religions, the 'spiritual dimension' is detached from the 'natural dimension' and the spirit is divorced from

3.We take here for our choice of proponents following the position of Kant between rationalism and empiricism. For Von Humboldt, Kant is 'one of the few philosophers who have escaped the imputation of impiety' (Von Humboldt 1858:66). The laws of nature as we understand them only existed because our mind interpreted them. We see things only as they appear to us.

4.Alexander von Humboldt and his brother, Wilhelm, used to attend the most prominent salon in Berlin, where Friedrich Schleiermacher was a constant presence. It seems that Schleiermacher's Romantic theology was based on his conviction that all intellectual discourses (theology included) should be modelled based on 'sociable practices'. The common point of all three (the two Von Humboldt brothers and Schleiermacher) appears to be their 'experience of sociability in Berlin saloons' especially that of Rahel Levin Varnhagen. This saloon was an 'alternative society' where the then social traditions were not only debated but also severely criticised, including contemporary patriarchalism and traditional theology (Fuchs 2020: including contemporary patriarchalism and traditional theology (Fuchs 2020 : 232-233). Thus, the role of women was considered crucial for society in this Berlin saloon and so was the importance of a theology which is not anchored in revelation but in human feelings. Together with Schleiermacher, Wilhelm and Alexander von Humboldt were part of a circle of intellectuals who rejected traditional authoritie (such as the church and societal customs) in favour of their personal views based on social interaction and common-sense conclusions (in the sense that what they agreed upon seemed more agreeable than the authoritarian teachings and customs of the institutions of the late 18th and early 19th century German society). nature. Mancuso could conclude that God is 'above being' and consequently above nature (Mancuso 2002:29).

Therefore, in rejecting the traditional perspectives ${ }^{5}$ on nature offered by revealed religions, Mancuso indicates his preference for 'cosmic religions' or religious systems that are not based on sacred books but rather on beliefs anchored in nature's reality. According to Mancuso, cosmic religions postulate the correlation between spirit and nature. Religion is a conglomerate of myths, so the creation and the fall convey more truth than individual interpretations of historical events (Mancuso 2005:84-85, 96). To use his phrases, the 'spiritual dimension' and the 'natural dimension' do not only overlap; they are the same reality (Mancuso 2002:29), which confirms God's absence from the realm of nature.

There is no difference between nature and spirit, no distinction between nature and God in cosmic religions because, according to these systems, spirituality derives from 'the consciousness of nature' in a way which makes use of what Mancuso presents as 'meditation about the natural flow of life' (Mancuso 2002:29). Mancuso needs to distance himself and his perspective on nature from the tenets of revealed religions not only based on his conviction about the coessentiality of nature and spirit but also because he sees no logic in placing anything, not even God, above nature, which attests to his belief in God's absence in nature. For instance, he emphasises that both the Torah and the Quran - and implicitly the Christian New Testament as anchored in the Torah - present God as 'nature in itself' or 'counter-nature' (Mancuso 2002:29).

Von Humboldt never even mentioned the word 'God' in Cosmos. Yet, he contended that everything was part of a never-ending activity of animated forces. Nature was a living whole where organisms were bound together in a net-like intricate fabric (Wulf 2015:290). Von Humboldt believed that both the internal and external worlds are inseparable and that the eye is the organ through which we view the world, and interpret and define it. He treated nothing in isolation and found an inner correlation between all aspects of nature. There is much in common with James Lovelock's Gaia hypothesis (1979) because he describes the earth as a natural whole animated and moved by inward forces (thus predating Lovelock's ideas by more than 150 years).

Mancuso's and von Humboldt's cynical take on the Christian religion, especially its doctrinal view of nature, is anchored in the conviction that 'Christianity is not the religion of life' (Mancuso 2002:30). Von Humboldt (2014:450) is very critical towards the Incas' indigenous religion and compared it to the 'theocracy' of the 'slave states' in the southern part of the United States of America. This also means that Christianity is not the religion of nature, according to their logic. Even if

5.It is, however interesting that Mancuso has a very dated view of three traditions mentioned. See the interpretation of John Haught (1995:19) in this regard: 'Rooted in the story of Abraham, the prophetic faith traditions invite their followers to look for the promise that lies in all things. Judaism, Christianity, and Islam think of for the promise that lies in all things. Judaism, Christianity, and Islam think of
"genuine" as a confidence that new life undreamed of possibilities are latent even in the most desperate situation'. 
Mancuso exemplifies his dictum by references to the Crusades and the military orders within Catholicism which massacred people across many centuries, Mancuso's main contention against Christianity is not historical but philosophical. As such, he equates nature with life, and in so doing, he connects both with the idea of sacredness. According to Mancuso, Christianity sees life as sacred only in as much as it originates in God (Mancuso 2002:30); hence, nature is sacred because it is God's creation. The sacrality of nature is given not by its existence and by its reality or even by its inner constitution and its ontology but by connecting with God's reality, existence and ontology. As far as Mancuso is concerned, such a logic defies nature's very reality: if it results from God's creation, nature is no longer ascribed primary importance but only a secondary significance. This explains Mancuso's need to present God as absent so that nature is bestowed the first and sole importance as constitutive of material reality.

What Mancuso is attempting to do is provide a view of nature that provides and endows nature with an intrinsic value by its material reality and detaches this natural philosophy from that of traditional revealed religions that see God as 'the absolute patron of life' (Mancuso 2002:30). However, Mancuso's concern is not related to an ontologically real God who created life and thus exercises sovereignty over it; Mancuso does not believe in such a God anyway because nature is God in his theology. Conversely, God is paradoxically present in nature, and the very fabric of nature confirms his absence. Therefore, it is evident that Mancuso's perspective on nature provides ample evidence favouring the presupposition that God should be seen neither as absolute patron of life nor as absolute patron of nature. Why? Because, in Mancuso's theology, even if there is no ontologically real God who exists beyond nature, the conviction that such a God does exist is accepted, proliferated, and enacted by people; and it is in this respect that Christianity - alongside Judaism and Islam - can be detrimental to the very reality of nature. According to Mancuso, if people believe in a supernatural God, they will respect him, not nature (Mancuso 2002:31), or not in the first place. Respect for nature and nature alone is what Mancuso tries to establish by juxtaposing nature with the spirit and with God. In Mancuso's theology, however, God is not a supernatural and transcendent being characterised by absolute alterity and real ontology; in this respect, God is fundamentally absent concerning nature. God is only a potentially detrimental concept to nature if not included in nature itself to confirm his absence from it.

Von Humboldt's holistic approach, including art, history, poetry and politics, has fallen today out of favour (Wulf 2015:396). The reason is that scientists of the 20th century preferred to dissect, analyse and investigate rather than move to interdisciplinary methods and the concept of a global force. Von Humboldt was not known for a specific discovery, but for his worldview and the idea of 'God' that is obsolete in this construct of reality. Von Humboldt was raised during the Enlightenment, striding forward along a progress trajectory not caring for nature's well-being.
Von Humboldt feels strongly about one common and equal humanity. All men are equal, and no race is above another. We all came from one root. This we promote, says Von Humboldt (1858):

$[B] y$ striving to remove the barriers which prejudice and limited views of every kind have erected among men, and to treat all mankind, without reference to religion, nation, or color, as one fraternity, one great community, fitted for the attainment of one object, the unrestrained development of the physical powers. (p. 506)

\section{Nature as salvation}

If Mancuso postulates God's absence through God's very inclusion as a concept into the reality of nature, how does he embed God in nature to confirm his absence from it? The answer is quite simple by using the notion of religion. According to Mancuso, religion is constitutive to the human being, and the human being is part of nature, so religion must play a crucial role within the economy of nature. Here is Mancuso's reasoning that the key aspect of religion is not God, but salvation (Mancuso 2002:72). God is absent in relation to nature; his presence cannot be scientifically ascertained within nature, so the idea of God cannot be so vitally important for nature. At the same time, as religion is part of nature, the same idea of God cannot be so crucially meaningful for religion. If this is true, and it is according to Mancuso's logic, then another idea should be counted as sine qua non in religion, and that is the notion of salvation. Mancuso builds his argument on the conviction that whilst there are religions that do not know God's idea, all religions deal with salvation one way or another (Mancuso 2002:72). Hinduism, Buddhism, Jainism and Confucianism are all religions that work without the idea of God, but they all focus on searching for and obtaining salvation. They all speak about divinity and eternity, but not about 'God as distinct from the universe' (Mancuso 2002:72), which translates as 'God as distinct from nature' in Mancuso's theology.

Mancuso reveals that religion can neither be detached from the idea of salvation, nor can salvation be detached from the reality of religion. But as religion is part of nature, salvation cannot be separated from the reality of nature. Salvation is a need, a basic human need, and it is in this capacity as fundamental human need that salvation is so crucially meaningful for the reality of nature. According to Mancuso, 'the religious dimension is constitutive to the human being' (Mancuso 2002:72), which demonstrates that - at least within Mancuso's reasoning - religion is constitutive not only to the human being but also to nature via the mediation provided by the human being. A fervent upholder of evolutionary theories, Mancuso appears to be convinced that the human being has been homo religiosus from the very instant he became homo sapiens (Mancuso 2002:72). In other words, reason and religion can and should coexist in harmony within the human mind and throughout the reality of nature for as long as the idea of God remains embedded in nature and does not reveal a supreme being beyond nature. For Mancuso, religion is nothing but the awareness of limitation; 
the human being became religious when he realised his limits as part of his existence in nature. Therefore, Mancuso contends that religion is constitutive not only to the human being but also to nature through its existence. The realisation of limitation is the foundation of religion because the idea of salvation is the human being's attempt to deal with his physical constraints within the reality of nature.

Nevertheless, to make sense of his existence, human beings must see salvation as virtually part of nature, and this spiritual awareness is provided exclusively by religion. Thus, according to Mancuso, religion is about finding a remedy to the human being's painful awareness of his limitations, but this remedy can only be found in nature, not beyond it (Mancuso 2002:73). Therefore, nature is the locus of religion and the purpose of religion; the remedy of salvation must be part of nature, so there is no salvation outside nature. Mancuso explains that the human being's acute problem is not becoming aware of our limitations, including death, but finding a remedy, a way to save our life from the inexorable reality of our natural limits. In other words, the human being must search for salvation in nature because we are 'inevitably connected to life' (Mancuso 2002:73). As far as Mancuso is concerned, the human being can do - and we did for many millennia - without art and science, but we cannot live without religion. The human being cannot live without understanding our place in the world and our role in nature; we must find a way to solve the 'enigma of life' through some salvation, the 'existential sense of religion(s)' (Mancuso 2002:73). But as religion is constitutive to nature, it stands to logic that, for Mancuso, finding salvation can be achieved only in nature; therefore, understanding nature is synonymous with finding salvation. In other words, Mancuso's logic dictates that nature is not only the context but also the content of human salvation.

Von Humboldt does not use God, sin, faith, salvation or eternity in his multivolume work, named Cosmos, nor in his

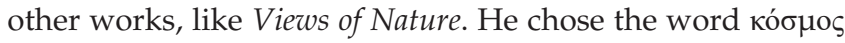
from ancient Greek where it meant order and beauty, as 'created through the human eye' (Wulf 2015:308). The external physical world is brought into a relationship with the inner world of the mind. Salvation is for Von Humboldt (1858) not only the peaceful charm uniformly spread over the face of nature that moves the heart, but:

[A]ll that the senses can but imperfectly comprehend, all that is most awful in such romantic scenes of nature, may become a source of enjoyment to man, by opening a wide field to the creative powers of his imagination. (p. 33)

\section{Nature as physics}

The fact that nature is characterised by salvation is of extreme importance for Mancuso's perspective on nature. There are at least two reasons for this realisation. Firstly, nature is synonymous to the universe, which means that the reality of nature is the same as the universe's reality, and secondly, the universe is also characterised by salvation. In other words, the universe is salvific because nature is salvific. But how can this be if the universe is also wild or ferocious, as Mancuso himself depicts it (Mancuso 2005:46)? This is how Mancuso explains his view of the universe as nature: its physicality gives its ferociousness or that nature is fundamentally physical, so the universe is essentially material. The physical reality of nature as the universe is material, and it can be measured and quantified. Nature, as physics, is one of Mancuso's most essential components of his perspective on nature. Everything in nature exists physically. Everything which exists in nature can be seen and measured: the universe in its entirety - or at least as far as we can see of it, the billions of galaxies, our solar system, our planet, its ecosystems, the human body, the organs which are part of it, the cells, the atoms, the protons and neutrons, the quarks, the electrons, and the photons (Mancuso 2005:46); everything which exists and can be seen, can also be measured. Consequently, if nature is physical and salvific at the same time, then salvation consists of understanding nature and how it works.

Von Humboldt's lifework was to provide a physical description of the universe, and he devoted almost a lifetime to the accumulation of materials for it. The first volume of his three-volume Cosmos comprised a sketch of all that was then known of the physical phenomena of the universe. The second volume comprehends two distinct parts: poetry, landscape paintings and the cultivation of exotic plants in the first part and, in contrast, discovering discoveries in science and the corresponding stages in human civilisation in the second part. The third volume presents the great Picture of Nature $^{6}$ (Von Humboldt 1858:5). This 'Naturgemälde' was produced in South America and published as a $3 \times 2$ foot drawing. It strikingly illustrated nature as a web in which everything was connected (Wulf 2015):

Instead of placing plants in their taxonomic categories, he saw vegetation through the lens of climate and location: a radically new idea that still shapes our understanding of ecosystems today. (p. 103)

Nevertheless, to understand how nature works to attain salvation, we must realise that there is a force that governs the universe, and that is gravity, according to Mancuso. Why is gravity necessary for our understanding of nature? Because gravity demonstrates that spacetime is not only curved but also distorted by mass-energy. In Mancuso's theology, this appears to be the most basic understanding of nature because the more mass-energy is concentrated in one point, the more the time and space attached to it become curved (Mancuso 2005:47). This is vital for a correct view of nature because, as Mancuso points out, there is a direct connection between the mass and energy, on the one hand, and space and time, on the other (Mancuso 2005:48). Mass, energy, space and time are all characteristics of the universe in its capacity as nature and fully aware of them. The way they work together represents genuine salvation for human beings. Why?

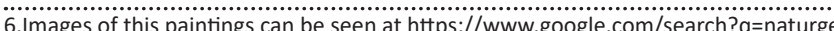
6.Images CCIQIBBKAI CCIQt8BKA $\mathrm{rc}=5 \mathrm{Mi3g} 5 \mathrm{D} 6 \mathrm{Yp} 2 \mathrm{gLM}$ and is not printed in this text because of copyright. This is comparable to the Tree of Life as a suitable simile for describing the meta-narrative of life on Earth, see https://www.nsf.gov/news/news_summ.jsp?cntn_id=124386. 
Because understanding how nature works, how the universe exists, and how all its parts are joined together in their physicality is a step towards knowing how human beings work. According to Mancuso, understanding nature is understanding human beings, so when human beings understand nature, they should understand themselves at least in theory. In Mancuso's own words, 'I am mass-energy. Every human being is' (Mancuso 2005:48), and every human being is part of the universe, an integrative element which belongs to nature.

Understanding nature as physics is so vital for both the proponents because we see the universe as constituted by space, time, mass and energy and because the very element that makes nature physical is matter. Furthermore, matter models space-time; concretely, the distribution of matter and energy in the universe distorts space-time by curving it (Mancuso 2005:48) - this is Mancuso's foundation for his understanding of nature on Stephen Hawking's explanation about general relativity (Hawking 2001:36). In other words, according to Hawking, whom Mancuso cites consistently, space-time is curved not only by large objects or by mass, but also by energy. It is at this point that Mancuso takes over and turns physics into theology. As energy distorts space-time and human beings are energy, human beings also distort space-time by curving it, but turning it towards itself; concretely, human beings distort space-time by turning it towards themselves. Even more importantly, and Mancuso highlights this aspect emphatically, every human being has its reality which converges towards itself from the very second when its mass-energy distorts its space-time (Mancuso 2005:48). Mancuso explains that every human being is a gravitational field that interacts with and is influenced by other gravitational fields or other human beings (Mancuso 2005:48). In this respect, general relativity speaks about human beings, so understanding nature as physics is understanding ourselves - and it is in this knowledge of nature, ourselves included, that salvation resides.

Therefore, Mancuso needs to explain that understanding nature as physics is foundational for human salvation because knowing how the universe works leads to an understanding of how we work. Knowing what the universe is, is equalled to knowing what we are. And knowing why the universe works as it does is knowing why we work as we do. This, however, is not everything and is certainly not sufficient for a complete appropriation of salvation. Nature is physics and spirit, and it is in this capacity, nature reveals to us what its physical side cannot convey. The physicality of nature teaches us that we are mass, that we are, as Mancuso puts it, 'muscle' (Mancuso 2005:48). However, what physics cannot teach us is why and how we work as 'pure energy' and why it is much more important to understand 'human character' (Mancuso 2005:48). Almost everything in nature, virtually all the physical components of the universe, is subject to gravity because if energy transforms itself into a mass, it generates gravitation force. However, if it does not, then it remains a mass that cannot exert any influence, like subatomic particles that are not influenced by gravity
(Mancuso 2005:49-50). In other words, almost everything within us is under the force of gravity, but there is something which escapes it. Hence Mancuso's question: what if these subatomic particles which are not influenced by gravity speak of our eternity; what if they are an image of the human soul? (Mancuso 2005:50) The question is rhetorical for Mancuso. Nature as physics teaches us that salvation is understanding who we are as human beings and how we work as part of the material universe. In this respect, matter itself reveals that whilst we are almost entirely under the influence of gravity, there is something material within us perhaps our soul - which escapes it and acts as a free agent despite its material and physical constitution.

Creation, therefore, is according to Simuț's (2011) interpretation of Mancuso,

$[N]$ ot necessarily a historical event but rather an interpretation of evolution because, while science fosters data and information to be analysed scientifically, theology (as well as philosophy) makes use of these data to create a worldview. (p. 138)

\section{Nature as biology}

If nature as physics allows us to understand that, as human beings, we are characterised both by necessity (exemplified by gravity and seen in death and selfishness; Mancuso 2005:61) and freedom (revealed by subatomic particles and embodied by truth and goodness; Mancuso 2005:61), nature as biology takes us a little further down the road of salvation. Mancuso's somewhat gnostic perspective on salvation human beings are saved by acquiring knowledge about nature and themselves and whether there is any spiritual significance attached to such knowledge - continues along with the same naturalistic features but with specific references to biological constitution of human beings. In short, whilst physics teaches us that gravity reigns supreme in nature, biology confirms gravity's position as 'queen' of the living, or all living organisms (Mancuso 2005:51). At the same time, biology teaches us that life in nature exists by exerting force, in the sense that living entities forcibly act upon other living entities. According to Mancuso, this is the very law of metabolism: the billions of cells within a living body, which are in perpetual motion as they find nutrients and reproduce, show no hesitation in causing death in the process (Mancuso 2005:51).

Moreover, the law of metabolism knows 'no rest or mercy', which indicates that life itself is restless and relentless in causing death within the material realm of nature as physics. Thus, understanding nature is understanding the force of gravity which, in biology, is exemplified by eros, the 'law of the mutual attraction of bodies' (Mancuso 2005:52). In this respect, gravity is more vital than human will, eros is more powerful than human reason, and attraction is mightier than freedom (Mancuso 2005:52).

According to Mancuso, understanding nature as physics should be done by understanding nature as biology, explicitly finding out how human beings function as bodies. 
'This world is this body', Mancuso writes, and its final destiny is 'to return to dust' (Mancuso 2005:52), a poignant indication that physics and biology are both constitutive of nature or, conversely, that nature cannot be understood, not properly anyway, without basic knowledge of physics and biology. And as salvation resides in this kind of experience, of both physics and biology as features of nature, awareness of how the human body works is a crucial instrument in this respect. Thus, Mancuso's initial phrase 'this world is this body' is followed by a mere addition, 'this world is above all this mortal body' (Mancuso 2005:52). Therefore, a comprehensive perspective of nature involves the reality of physics and biology and full awareness of death and one's mortality. In Mancuso's theology, the world is the realm of death, and knowing the world is something we acquire by growing more and more awareness of death, 'this world is the death which awaits me; this macabre dance which death performs around my body' (Mancuso 2005:52). Therefore, as far as Mancuso is concerned, developing a proper perspective on nature is entirely dependent on becoming acquainted with the reality of death. How we die is not only a matter of personal concern but - even more importantly an issue of obtaining salvation through the mediation provided by the knowledge of nature as physics and biology.

Wulf (2015:256) makes us aware that Charles Darwin was so impressed by Von Humboldt's research, which he first read as a student at Cambridge, that it had become the driving force for Darwin to volunteer as a naturalist in the HMS Beagle. As Darwin explored Santiago, he noticed the plants and animals through Von Humboldt's eyes. Subsequently, Darwin wrote to his brother to send Von Humboldt's 'Views of Nature' (Von Humboldt 2014) to him in Uruguay where he would have been at the time. Von Humboldt taught Darwin to investigate nature not from a one-sidedness but from within and without. This led to both a microscopic and telescopic understanding of reality. Von Humboldt believed that the problem of movement of plants could not be solved: 'The science of plant and animal geography was not about the investigation of the origin of beings' (Wulf 2015:275). Darwin underlined this specific sentence in his copy of von Humboldt's 'Personal Narrative', and, as we know, found the solution eventually in the concept of natural selection. The wealth of life is spread everywhere and transcends death as a mere natural phenomenon (Von Humboldt 2014:93).

Death is the key to understanding nature, the reality which deciphers and informs our knowledge of nature, based on investigations into the realm of physics and biology. If knowing nature as physics and biology is salvation for human beings, then understanding death is the instrument that allows us to make sense of 'mechanics' of death as part of nature. Here, Mancuso's understanding of nature as spirit contributes significantly to developing our perspective on salvation. Delving into the reality of death is an exercise which appears to belong to the spirit, or the human being's capacity to see beyond the physics and biology of nature into ascribing meaning and significance to life in the world. According to Mancuso, understanding death is understanding eternity because 'had it not been for death' nobody knows how much 'moral degradation (or spiritual putrefaction) could have been elevated to eternity' (Mancuso 2005:52). Death is the hermeneutical key that deciphers the significance of life in nature's physicality and biology; without death, spirituality would be impossible, and discernment would be unachievable. Mancuso seems to believe that death is the same decoding machine that helps us to understand why we exist and how we live in nature despite the limitations of physics and biology constraints. In the absence of death, understanding nature would have been unattainable, and so would have been salvation itself.

In speaking about death, Mancuso uses two metaphors. Firstly, he describes death as 'the great scalpel' which cuts deep not only into us but also amongst ourselves to make us 'worthy of eternity' (Mancuso 2005:52). In other words, death separates what is worthy from what is not, what deserves eternal remembrance from what does not; so, death combines Mancuso's perspective on nature as spirit and God with his understanding of nature as physics and biology. Human beings live in the world as physical and biological organisms, which can and perhaps should be remembered for as long as they live in such a way that their existence is characterised by spirituality. Secondly, Mancuso presents death as 'life's great midwife'; the reality which delivers us into non-existence having lived in the world as physical and biological entities (Mancuso 2008:52-53). Death acts upon human beings both biologically, through cellular mechanisms which eventually cause our demise, and historically, through wars or other human-engineered cataclysms that lead to genocide or mass destruction. According to Mancuso, awareness of death is coupled with an understanding of the pluriformity of life forms; in which case, salvation is the knowledge that we are 'biologically negligent greatness' (Mancuso 2005:53) in the world of nature. Thus, Mancuso suggests that a proper understanding of nature should include knowledge of the universe as physics and biology and permanent awareness of death as the key to a meaningful life within nature as spirit.

\section{Nature as awe}

Andrew Louth (2004:70) draws our attention to the fact that the origins of many medieval universities stem from the monastic schools teaching the trivium (grammar, rhetoric and dialectic) which has made way for the quadrivium (reading, thinking, pondering and contemplation). The ultimate concern was to look for God, being aware of God's presence in creation:

Right from Aristotle, and indeed earlier, the acknowledgement of the supreme value of contemplation, and the need that there be those who may devote their time to this, has been linked to acknowledgement that human beings are not simply earthbound entities. (p. 77) 
The old saying that beauty is in the beholder's eyes is applicable in both the discussed proponents' worldviews (Von HUmboldt 1858):

Science is the labor of mind applied to nature, but the external world has no real existence for us beyond the image reflected within ourselves through the medium of the senses. (p. 100)

The external world, ideas and feelings converged in the existence of the perceiver. 'The eye is thus made the medium through which we may contemplate the universe' (Von Humboldt 1858:109). For Mancuso, creation is ultimately a message which every human being must decipher during her or his journey within the life of this world (Mancuso 2002:138-161). Mancuso offers a comprehensive explanation of reality which emerges from a personal materialistic-experiential perspective on the world in its entirety. Religion becomes for him an existential hymn to the full meaning of life.

Mancuso contends that amazement at the beauty of creation is a familiar feeling of believers and non-believers (Mancuso 2013:n.p.). The conditions of beauty, which generate and sustain it, are:

- the inner harmony that comes from the balance and conciliation of love and strength

- external harmony with the community that requires recognising the right value to the reasons of others

- external harmony with the environment which is balance and reconciliation of the fundamental rights to work and health. The right to work is considered inalienable.

Von Humboldt was primarily an artist. He brought different fields of science in contact with the humanities, especially poetry and art. His conscience and aesthetics bring sheer delight to the researcher linking together pieces of the cosmic puzzle. Objectivity meant for him an 'embracing mind and imagination - intellect, poetry, and emotion - as multiple modes of access that allow humans to participate in the grand unfolding of the cosmos' (Von Humboldt 2014:22).

Mancuso's theology is like a refracting lens of a telescope that gathers and directs the world's light in new ways. This resonates with Von Humboldt when he says that we learn the world through our senses and 'phenomena of light proclaim the existence of matter in remotest space, and the eye is thus made the medium through which we may contemplate the universe' (Von Humboldt 1858:108-109). This makes the telescopic vision so essential. Creation is a message which every human being must decipher during her or his journey within the life of this world (Mancuso 2002:138-161).

\section{Conclusion}

The term 'consilience' (literally meaning jumping together!) was popularised by Edward O. Wilson (1998) in his book Consilience: The Unity of Knowledge in his search for a unified theory of knowledge in disciplines that range from physics to biology, the social sciences and the humanities. With this term, Wilson expresses a hierarchy of explanatory subsumptions with a subsequent reductionist epistemology. However, the first to apply this concept was William Whewell (1794-1866) upon whose insights of an emergent field of evolutionary biology, Charles Darwin relied heavily on. Von Humboldt drew together an extensive network of observers, explorers and scientists in every area of knowledge from all over the globe. In the Introduction to Von Humboldt's 'Views of Nature' (2014), the editors write a foreword, titled, 'Reclaiming Consilience,' stating:

Humboldt's work can be seen as a massive project in consilience, as he strove to weave the separate strands of geology, physiology, physical geography, geophysics, geographic distribution and movements of plant and animal species, vegetation patterns, anthropology and ethnography, linguistics, weather, climate, and more into a whole that today is most closely approached by the field called 'earth systems science'. (p. 19)

In the end, it is about bringing disparate phenomena together in a (social) construct or metanarrative. This is why Mancuso leans heavily on the perspective of myth to explain nature. 'Myths, however, can only be understood symbolically because symbols point to realities which happen in real life' (Simuț 2011:145). Myth, in other words, brings creation and science together. This is an exercise 'from below,' and the only way to talk about God is to think of him in terms of the spirit (Mancuso 2005: 97-99). Creation is therefore for Mancuso no doctrine, but a religious philosophy with mythological symbols.

Simuț (2011:151) concludes about Mancuso's theology as follows:

Mancuso's declared intention is to rebuild Christian theology from a perspective which dramatically reinterprets - even to the point of elimination - traditional hermeneutics in favor of a more scientific approach which is reportedly in accordance with the convictions and expectations of contemporary people. It is relevant to notice that, in doing so, Mancuso still works with the Bible which he uses quite often whenever he wants to make a point in order to support his theories. (p. 151)

It would be futile to apply, for example, John Calvin's Capita doctrinae (Inst. 4.1.12) to a theologian like Mancuso to determine his theological plausibility: firstly, because it is an anachronistic criterion, and secondly because he is not interested in repeating these classical tenets in his enterprise. He is a contemporary apologist endeavouring to converse with the 21st century's humans based departing from faith.

For the Jesuit magazine La Civiltà Cattolica, Vito Mancuso manages to 'deny or at least empty of meaning about a dozen dogmas of the Catholic Church,' thus fuelling the confusion. The magazine (in an article of February 2008 signed by Father Corrado Marucci to which Vito Mancuso replied with an article published in Il Foglio Quotidiano of 
10 February 2008) goes on to say that Vito Mancuso's theology starts from premises that are philosophically incorrect and neglects biblical data to end up in a sort of rationalism (Marucci 2008:n.p.). During a day of reflection organised at the Abbey of San Galgano in July 2019, Mancuso based his theology on his existential faith vis-à-vis a traditional theistic religion. ${ }^{7}$ He declared that this faith acknowledges as a three-fold form of beauty:

- the physical beauty of nature originated from the world

- moral beauty of the highest deeds and the brightest people, arising from humanity

- spiritual beauty originated from art.

Mancuso's supervisor of his doctoral thesis at the Lateran University wrote in the newspaper Il Foglio, dated 10 October 2017, that the enterprise of Mancuso 'raises the question of how to articulate Christian truth with the discoveries of contemporary science and self-awareness'. He adds: 'It is as if he were saying to theology: get to the point. And to culture: accept the challenge' (see: https://www.vitomancuso.it/critiche/).

William Brown (2010:13-16) provides quite sound (Biblical) hermeneutics for juxtaposing theology and science, which reminds of the hermeneutic circle of Hans-Georg Gadamer ([1989] 1975:292) as an iterative process through which a new understanding of a whole reality is developed by exploring the detail of existence. 'There is no more an isolated horizon of the present in itself than there are historical horizons which have to be acquired. Rather, understanding is always the fusion of these horizons supposedly existing by themselves's (Gadamer [1989] 1975:305).

Against this salient background, Brown (2010:14) proposes the following steps of his iterative process of the text ${ }^{9}$ :

Step 1. Elucidate the text's perspective on creation within the text's own contexts.

Step 2. Associate the text's perspective on creation with the perspective of science.

Step 3. Appropriate the text in relation to science and science in relation to the text.

Alister McGrath (2006:194-203) applies this method of iteration and recapitulation to systematic theology as discipline when he says:

On the basis of both historical observation and theoretical observation, it is proposed that systematic theology operates based on an implicit iterative method, which needs to be made explicit and incorporated into discussion of theological method. (McGrath 2006:195)

7.See: https://www.grandeoriente.it/sulla-via-della-bellezza-sosta-a-san-galgano-ilvideo-della-lectio-del-filosofo-vito-mancuso/ (Accessed on 03 February 2021).

8.Italics in the original text.

9.It should be clear to the reader that the scope of this article transcends the traditional creation narratives, especially as they are recorded and complied canonically. 'Text' in this article, very much equals nature. Everything which happens in nature is natural and 'nature' as part of nature. Even the spirit is materia and natural, according to Mancuso's hermeneutics. William Brown (2010:241-244) comes with his comparative table in the Appendix uncomfortably close to a contrast approach of theology and science regarding creation stories (cf. Haught 2012:4). We prefer convergence, also called consonance (rather resonance), cooperation, contact or conversation.
This 'spiral staircase' relativises eventually all doctrines.

Although we referred to the concept of consilience regarding von Humboldt's enterprise, it is not in the authors' scope to achieve this with science and theology. However, if resonance becomes essential in understanding reality, faith is inevitable (Anselm). If a creation theology seeks plausibility, it requires the feedback-loop methodology of science. We all share one earth: the closer we all come to a point of omega, the closer we also come together and transcend differences.

Theology cannot advance the scientific quest for the underlying constituents of matter and the physical nature of causation. Science, in turn, cannot lay claim to knowing God and God's purposes. Both disciplines represent independent fields of inquiry. (Brown 2010:7)

Resonance has the potential to let new horizons emerge in our mutual endeavour to come to grips with reality and to map out certain TOMA.

By juxtaposing these two proponents of theology and science through elucidation, association and appropriateness, we dare to conclude that an enterprise from below is imperative: reality is an eco-sociological construct, the universe intrinsically interconnected, the coexistence of order and disorder within the world, and, 'God is Spirit' (Jn 4:24). The importance of 'seeing' correctly is clearly stated in the Prologue to Gospel of John. 'The Christian tradition offers a way of seeing nature, which allows its goodness to be discerned' (McGrath 2008:307). Or in the view of Schleiermacher ([1999] 2008:735):

The divine wisdom is the ground in virtue of which the world, as the scene of redemption, is also the absolute revelation of the Supreme Being, and is therefore good.

There is a need to interpret the natural world, integrate disparate observances and conceptualise a bigger picture meaningful to those engaged.

\section{Acknowledgements Competing interests}

The authors declare that they have no financial or personal relationships which may have inappropriately influenced them in writing this paper.

\section{Authors' contributions}

C.C.S. drafted a text on Mancuso. J.B. did the same on Von Humboldt. Then J.B. conceptualised the juxtaposition and drafted an argumentative text with coherent conclusions. C.C.S. and J.B. both proofread and approved the final version.

\section{Ethical consideration}

This article followed all ethical standards for research without direct contact with human or animal subjects. 


\section{Funding information}

This research received no specific grant from any funding agency in the public, commercial or not-for-profit sectors.

\section{Data availability}

Data sharing is not applicable to this article as no new data were created or analysed in this study.

\section{Disclaimer}

The views and opinions expressed in this article are those of the authors and do not necessarily reflect the official policy or position of any affiliated agency of the authors.

\section{References}

Brown, W.S., 2004, 'Resonance: A model for relating science, psychology, and faith', Journal of Psychology \& Christianity 23(2), 110-120.

Brown, W.P., 2010, The seven pillars of creation. The Bible, science and the ecology of wonder, Oxford University Press, Oxford.

Buitendag, J., 2012, 'Die noodsaaklikheid van habitat in ons definisie van menswees: Op soek na 'n eko-teologiese verstaan van menslike lewe', HTS Teologiese Studies/ Theological Studies 68(1), 1-8. https://doi.org/10.4102/hts.v68i1.1283

Fuchs, R., 2020, 'The politics of the female body in Louise Aston's and Fanny Lewald's Writings through the prism of the romantic theory of sociability and dialogue', in E. Krimmer \& L. Nossett (eds.), Writing the self, creating community. German Women authors and the literary sphere, 1750-1850, pp. 230-252, Camden House, Rochester, NY.

Gadamer, H.-G., 1989 [1975], Truth and method, 2nd edn., transl. J. Weinsheimer \& D.G. Marshall, Continuum, London.

Gould, S.J., 2014, 'Nonoverlapping Magisteria', Philosophical Aspects of Origin, Uniwersytet Zielonogórski nr 11. 7-21.

Haught, J.F., 1995, Science \& religion. From conflict to conversation, Paulist Press, New York, NY.

Haught, J.F., 2012, Science and faith, Paulist Press, New York, NY.

Hawking, S., 2001, The universe in a Nutshell, Bantam Books, New York, NY.
Lindbeck, G.A., 1984, The nature of Doctrine. Religion and theology in a Postliberal age, The Westminster Press, Philadelphia, PA.

Louth, A., 2004, 'Theology, contemplation and the university', Studies in Christian Ethics 17(1), 69-79. https://doi.org/10.1177/0953946804017001051

Lovelock, J.E., 1979, Gaia. A new look at life on earth, Oxford University Press, Oxford.

Mancuso, V., 2002, II dolore innocente: I'handicap, la natura e Dio, Mondadori, Milano.

Mancuso, V., 2005, Rifondazione della fede, Mondadori, Milano.

Mancuso, V., 2013, Il principio passione, Kindle edn., Garzanti, Milano.

Marucci, C., 2008, 'L'anima e il suo destino secondo Vito Mancuso', La civiltà cattolica (02 February).

McGrath, A.E., 2006, The order of things: Explorations in scientific theology, Blackwel Publishing, Oxford.

McGrath, A.E., 2008, The open secret. A new vision for natural theology, Blackwel Publishing, Oxford.

Michener, R.T., 2013, Postliberal theology. A guide for the perplexed, Bloomsbury, London.

Peters, T., Russel, R.J. \& Welker, M. (eds.), 2002, Resurrection. Theological and scientific assessments, William B Eerdmans Publishing Company, Grand Rapids, MI.

Schleiermacher, F., [1999] 2008, The Christian faith, 2nd edn., eds. H.R. Mackintosh \& J.S. Stewart, T\&T Clark, London.

Simut, C.C., 2011, 'The theology of creation in Vito Mancuso's radical theology', Acto Theologica 31(1), 138-155, viewed from https://www.ajol.info//index.php/actat/ article/view/67286.

Tracy, D., 2010, 'Western Hermeneutics and Inter-Religious Dialogue', UChicago Voices 2010, a171, 1-26, viewed 10 February 2021, from https://cpb-us-w2.wpmucdn. $\mathrm{com} /$ voices.uchicago.edu/dist/a/171/files/2010/04/Tracy-David-WesternHermeneutics-and-Inter-Religious-Dialogue.pdf.

Von Humboldt, A., 1858, Cosmos - A sketch of the physical description of the universe, vol. 1, Kindle edn., transl. E.C. Otto and eBook prepared by Amy Zelmer, Harper \& Brothers, New York, NY.

Von Humboldt, A., 2014, Views of nature, Kindle edn., transl. S.T. Jackson, L.D. Walls, eds. M.W. Person, The University of Chicago Press, Chicago, IL.

Wilson, E.O., 1998, Consilience: The unity of knowledge, Alfred A. Knopf, Inc., New York, NY

Wilson, E.O., 2006, The creation. An appeal to save the life on earth, Kindle edn., W.W. Norton en Company, Inc., New York, NY.

Wulf, A., 2015, The invention of nature, Kindle edn., John Murray Publishers, London. 